\title{
Review \\ Heparin and Its Derivatives: Challenges and Advances in Therapeutic Biomolecules
}

\author{
Nipa Banik $\left.{ }^{1,+} \mathbb{(}\right)$, Seong-Bin Yang ${ }^{1,+}$, Tae-Bong Kang ${ }^{1}\left(\mathbb{D}\right.$, Ji-Hong Lim ${ }^{1,2}$ and Jooho Park ${ }^{1,2, *(\mathbb{C})}$ \\ 1 Department of Integrated Biosciences, Graduate School, BK21 Program, Konkuk University, \\ Chungju 27478, Korea; baniknipa@gmail.com (N.B.); tjdqls414@gmail.com (S.-B.Y.); \\ kangtbko@kku.ac.kr (T.-B.K.); jhlim@kku.ac.kr (J.-H.L.) \\ 2 Department of Biomedical Chemistry, College of Biomedical \& Health Science, Konkuk University, \\ Chungju 27478, Korea \\ * Correspondence: pkjhdn@kku.ac.kr \\ + These two authors contributed equally to this work
}

Citation: Banik, N.; Yang, S.-B.;

Kang, T.-B.; Lim, J.-H.; Park, J.

Heparin and Its Derivatives:

Challenges and Advances in

Therapeutic Biomolecules. Int. J. Mol.

Sci. 2021, 22, 10524. https://doi.org/

10.3390/ijms221910524

Academic Editor: Nobuaki Higashi

Received: 16 August 2021

Accepted: 28 September 2021

Published: 29 September 2021

Publisher's Note: MDPI stays neutral with regard to jurisdictional claims in published maps and institutional affiliations.

Copyright: (c) 2021 by the authors. Licensee MDPI, Basel, Switzerland. This article is an open access article distributed under the terms and conditions of the Creative Commons Attribution (CC BY) license (https:// creativecommons.org/licenses/by/ $4.0 /)$
Abstract: Heparin has been extensively studied as a safe medicine and biomolecule over the past few decades. Heparin derivatives, including low-molecular-weight heparins (LMWH) and heparin pentasaccharide, are effective anticoagulants currently used in clinical settings. They have also been studied as functional biomolecules or biomaterials for various therapeutic uses to treat diseases. Heparin, which has a similar molecular structure to heparan sulfate, can be used as a remarkable biomedicine due to its uniquely high safety and biocompatibility. In particular, it has recently drawn attention for use in drug-delivery systems, biomaterial-based tissue engineering, nanoformulations, and new drug-development systems through molecular formulas. A variety of new heparin-based biomolecules and conjugates have been developed in recent years and are currently being evaluated for use in clinical applications. This article reviews heparin derivatives recently studied in the field of drug development for the treatment of various diseases.

Keywords: heparin; heparin derivative; polysaccharide; anti-cancer effect; bioconjugate

\section{Introduction}

Heparan sulfate (HS) is a natural component of the extracellular matrix (ECM) that is abundantly expressed at cell surfaces in vertebrate tissues as part of proteoglycans (PGs). These proteoglycans carry branches of glycosaminoglycans (GAG) improving a lot of critical physiological processes. Sulfated natural GAG molecules are chondroitin sulfate (CS), heparin, heparan sulfate (HS), keratan sulfate, and dermatan sulfate (DS); non-sulfated natural GAG molecule is Hyaluronic acid (HA). Considering the disadvantages of the direct use of natural GAG, GAG-mimetic biomolecules have become the key of biofunctions these days [1]. Among GAGs, HS is composed of D-glucosamine and hexuronic acid units with many sulfate groups in a molecular structure and shows good biocompatibility and biodegradability [2]. It is a biomaterial that is essential for normal embryonic development, cellular homeostasis, and various pathological processes as well as neurodegenerative diseases [3-5]. For example, abnormal heparan sulfate storage in lysosomes develops primarily mucopolysaccharidosis $111 \mathrm{~B}$ [6].

Heparin, whose structure and properties are similar to those of heparan sulfate, has been used clinically as an anticoagulant. Heparin is an FDA (Food and Drug Administration)approved drug used for patients at the risk of blood clots. Heparin is found in animal tissues in forms such as heparan sulfate but differs in that it is used in medicines based on its strong anticoagulation effects [7]. Although heparin is mostly used as an anticoagulant, it has great potential for use as a biomolecule for the treatment of inflammation, injury, or malignant tumors [8]. In addition, the various advantages of heparin have led to the development of similar biomolecules that mimic it. For example, different types of heparin 
mimetics were developed as di- and tri-block copolymers containing anionic poly (sodium 2-acrylamido-2-methylpropane sulfonate (PAMPS) acting as an anticoagulant component with polyethylene glycol (PEG) [9].

Heparin and its derivatives have been clinically developed to optimize the anticoagulant effect while decreasing the systemic toxicity $[10,11]$. Heparin is a linear macromolecule consisting of a heterogeneous mixture of saccharide chains. Unfractionated heparin (UFH) is a naturally occurring glycosaminoglycan ranging in molecular weight (MW) from approximately $16,000 \mathrm{Da}$ [12]. The problem with the use of UFH as a safe medicine is that its molecular size is not optimized for regulating the blood coagulation process or target inhibition. The average molecular weight of UFH is much greater than the small heparin binding site of antithrombin or Factor Xa (58,000 Da), which is a target for exerting anticoagulant effects. Low-molecular-weight heparins (LMWHs) derived from UFH have been widely used due to their excellent efficacy and low number of side effects due to their optimized molecular size. For many indications, LMWH is usually preferred over UFH due to its good predictability, low number of side effects, and lower risk of inducing bleeding [6]. In this line, smaller heparins such as very-low-molecular-weight heparins (VLMWHs) or ultra-low-molecular-weight heparins (ULMWHs) have also been introduced by researchers. Furthermore, a small synthetic heparin pentasaccharide named fondaparinux was developed as an alternative anticoagulant with an optimized molecular weight and sequence; relatively, a small heparin derivative with a small molecular weight is easy to synthesize.

Studies of various medical uses of heparin derivatives are not limited to analyses of their anticoagulative effects. To date, many heparin derivatives and conjugates have been developed as new drug candidates or theranostic (diagnosis and therapy) agents like probes. Their therapeutic effects have been studied for use in anti-cancer, wound-healing, anti-viral, and anti-inflammatory therapies $[13,14]$. In particular, a range of studies suggest that heparin derivatives and conjugates can inhibit tumor growth and metastasis by suppressing many tumor-related factors (Figure 1) $[1,10,11]$. Heparin-based biomolecules are able to bind to vascular endothelial growth factor (VEGF), basic fibroblast growth factor (bFGF), P-selectin, CXC motif chemokine ligand 12 (CXCL12, also called stromal-derived factor1; SDF-1), and heparanase, affecting cell migration, adhesion, and angiogenesis [15-17]. Therefore, in this review, we summarize the current advances and challenges in the development of heparin-related biomolecules such as heparin derivatives and conjugates for their successful clinical application.

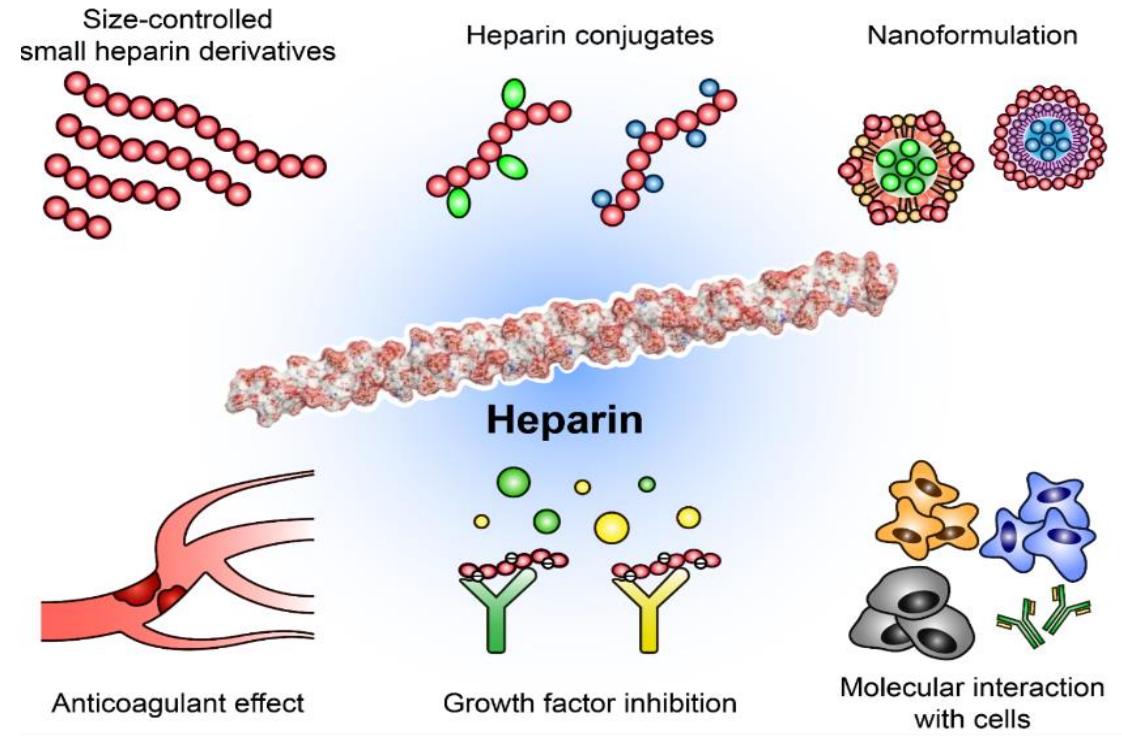

Figure 1. Schematic illustration of heparin derivatives and applications. Various derivatives have increased the variety of therapeutic uses available, which can serve not only as anticoagulants, but also as functional biomolecules for diverse diseases. 


\section{Limitations and Challenges for Using Heparins for Medical Purposes}

The decades-long clinical use of heparin and heparin derivatives has recently been challenged due to the development of competitive drugs. Heparin is an FDA-approved safe drug, but other competitive anticoagulants that can be used orally have been emerging in the pharmaceutical market. It has been well documented that the administration of UFH or LMWH is the current safe and standard treatment for deep vein thrombosis (DVT), pulmonary embolism, and stroke prevention. The safety and efficacy of the use of heparin have been confirmed over decades-long studies, and heparin is still in clinical use in many high-risk patients $[18,19]$. However, UFH and LMWHs are difficult for the body to absorb when administered orally because they have large molecular weights of over $4000 \mathrm{Da}$ and exhibit strong negative surface charges [20,21]. Since even very small molecular heparins exceed $1500 \mathrm{Da}$, normal heparin derivatives also cannot be absorbed in the gastrointestinal (GI) tract when they are administered orally [22]. However, in the case of newly developed direct oral anticoagulants (DOACs), which act on similar targets with low molecular weights, they are able to be used as oral medicine for patients [23,24]. For this reason, DOACs including rivaroxaban and apixaban are increasingly being used to prevent venous thromboembolism after surgery or arthroplasty [25]. Considering the importance of anticoagulants, which should be used daily for preventive purposes, DOACs may continue to increase their share of the anticoagulant market as a substitute for heparins.

With the various studies of heparin as functional biomolecules, heparin and its derivatives have been found to have various therapeutic functions in treating disease. In particular, the molecular structure of heparin is similar to that of HS, a component of the $\mathrm{ECM}$, and is capable of biological interactions with various proteins and cytokines $[3,5]$. For example, the currently used heparin derivatives could impact cancer progression in cancer patients via anti-angiogenic and anti-metastatic effects [26]. The administration of LMWH to cancer patients increased the survival rate in a manner that was not related to the anticoagulant effect of heparin [27-29]. Additionally, heparins could act as effective wound-healing accelerators, increasing angiogenesis; as anti-viral agents that can inhibit human immunodeficiency virus; and as regulators of inflammatory arthritis, inhibiting cell accumulation and collagen destruction $[11,30,31]$. In addition, several heparin derivatives have been developed for non-anticoagulant applications. However, in order to use a heparin derivative for therapeutic purposes other than its anticoagulant effect, its anticoagulant effect needs to be eliminated. Additional molecular modifications such as periodate treatment, molecular modification, and size control can be used to eliminate the anticoagulant effect, but these methods have not been completely validated in clinical studies [32]. It seems that the chemical conjugation of heparins with other molecules could result in an increase in biological activity or therapeutic effect with the loss of the intrinsic anticoagulant properties of heparin. Thus, an optimized heparin conjugate might be a good drug candidate. Therefore, it is important to develop and study an appropriate heparin derivative or conjugate suitable for potential clinical use.

\section{Various Heparin Derivatives and Conjugates for Optimizing Anticoagulant Effect \\ 3.1. Heparin Conjugates for Optimizing Anticoagulant Effects}

To overcome several problems of UFH, such as unwanted interactions with plasma proteins, low-molecular-weight heparin derivatives have been prepared and clinically used (Figure 2). The optimal heparin molecular structure and size might be derived through structural analysis of heparin based on computer simulation. Smaller heparins such as LMWH have shown better pharmacokinetic and pharmacodynamic profiles because their molecular size is optimized for targeting Factor Xa to exert anticoagulative effects [33,34]. Commercially available LMWHs include enoxaparin, nadroparin, tinzaparin, reviparin, and dalteparin [35]. Although their anticoagulant effects are more predictable and dosedependent than those of UFHs, they have higher anti-Xa/anti-lla activity ratios compared with UFH. Among the LMWHs, tinzaparin and dalteparin have molecular weights that are higher than those of others by 1000 to $2000 \mathrm{Da}$ [12]. On the other hand, the average 
molecular weights of enoxaparin and nadroparin are 4300-4500 Da. LMWH, those who have low molecular weight, have low activity against Factor lla (thrombin). Therefore, LMWH derivatives have a higher ratio of anti-Xa activity to anti-lla activity [36]. These substances are widely used across the world as anticoagulants [7,37]. There are subtle differences in the structure of the two LMWHs. Enoxaparin, for instance, is usually prepared from UFH via a chemical b-elimination reaction so that 1,6-anhydrosugar residues are present at the reducing end. However, nadroparin does not have a reducing end because it is obtained by nitrous acid depolymerization.

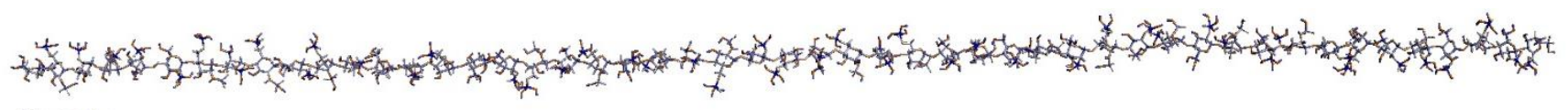
Heparin UFH (Unfractionated Heparin)
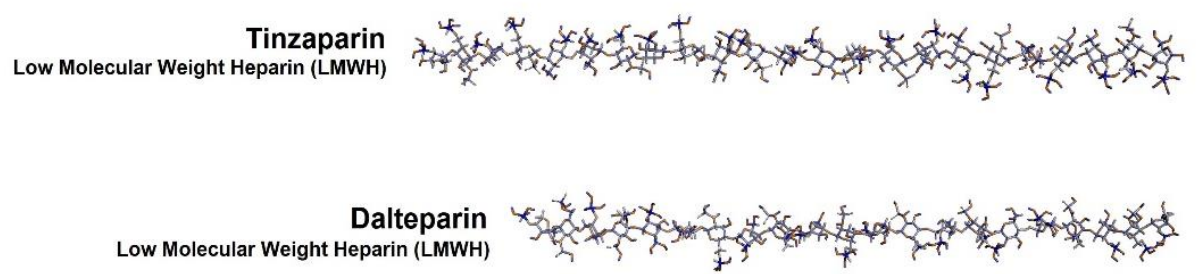

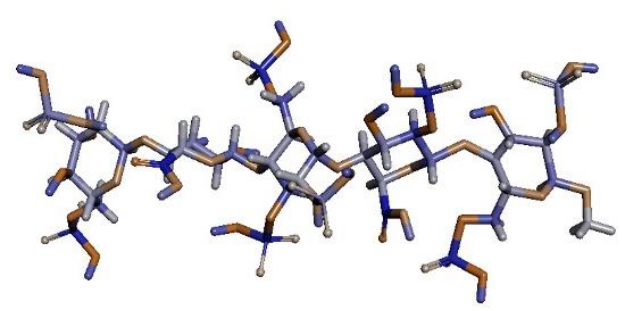

Fondaparinux

Synthetic heparin pentasaccharide

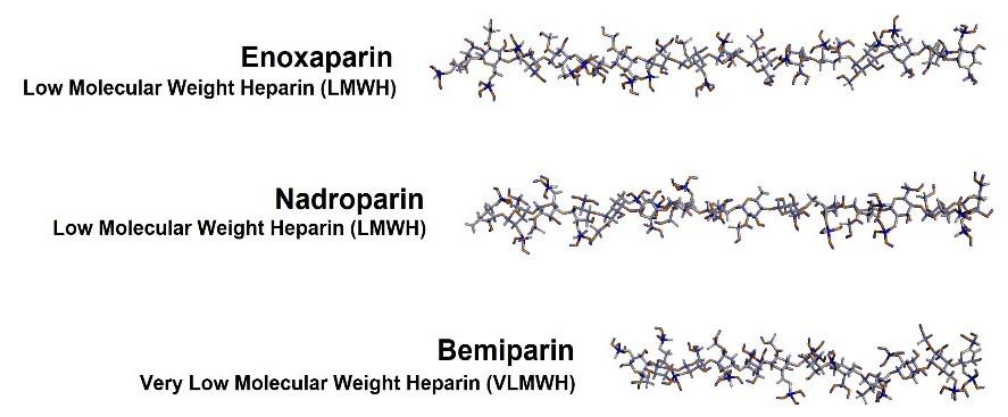

Very Low Molecular Weight Heparin (VLMWH)

Figure 2. Chemical structures of unfractionated heparin (UFH), low-molecular-weight heparin (LMWH), very-lowmolecular-weight heparin (VLMWH), and synthetic heparin pentasaccharide used as anticoagulants. Based on the main sequence of heparin, the molecular structure of heparin was specified through computer simulation to consider the molecular interaction with heparin related proteins. The molecules were generated from the solution structures of heparin obtained using an X-ray scattering model (protein data bank; PDB, 3IRL) [38]. The molecular structures of heparin were further modified using the ChemDraw 20.1 Professional (PerkinElmer) program based on their synthetic processes and average molecular sizes. The modified molecules were visualized using the Discovery Studio 2021 (BIOVIA) software.

It has been reported that very-low-molecular-weight heparins or synthetic low molecular heparin mimics can show Factor Xa-specific anticoagulant effects, resulting in a decrease in systemic toxicity [39-41]. The heparin binding site of antithrombin can accommodate a small number (five or more) of polysaccharide residues at high affinity sequence. In fact, the number of heparin saccharide rings that can bind effectively to antithrombin is limited to approximately five, meaning that very small heparins with an average molecular weight of 1800-2500 Da are sufficient for molecular binding [33,42]. Based on the structural information of the small heparin binding site, VLMWHs including semuloparin and bemiparin have been prepared and studied $[43,44]$. Furthermore, a size-optimized synthetic heparin mimic was chemically synthesized and developed, exploiting the appropriate heparin size and sequences [45]. Fondaparinux, a synthetic heparin pentasaccharide, was approved by the FDA for medical applications with consistent pharmaceutical parameters [46]. Taken together, these so-called VLMWHs or ultra-low-molecular-weight heparins (ULMWHs), including fondaparinux, showed a higher anti-Xa activity than other heparin macromolecules such as UFH or LMWHs. Therefore, these molecular-size-optimized ULMWHs or LMWHs have shown great potential in clinical applications as drugs with improved therapeutic 
effects and low toxic effects when compared with large UFHs [47]. The design of heparin derivatives can be optimized in terms of not only the molecular size and sequence but also the route of administration.

The oral delivery of heparin is important for patients with a high risk of clotting because the action of heparin is necessary for the prevention of thrombosis [22,48]. First, in order to improve the oral bioavailability of heparin, an oral formulation with an enhancer including sodium N-[8-(2-hydroxybenzoyl) amino] caprylate (SNAC) or sodium $\mathrm{N}$-[10-(2-hydroxybenzoyl)amino] decanoate (SNAD) was developed [49-52]. Then, chemical heparin conjugates such as low-molecular-weight heparin and deoxycholic acid conjugate (LMWH-DOCA) or heparin-lipid conjugate were synthesized for oral heparin delivery [53-56]. These oral chemical conjugates have also been widely studied for the treatment of various other diseases such as cancer $[13,57,58]$. The problem with these synthesized heparin derivatives and conjugates is that at least five intact heparin saccharide rings are required for therapeutic action, but they can be easily lost during synthesis, increasing the complexity. Therefore, a precise end-site-specific conjugation of heparin to preserve its heparin sequence was attempted; then, a new enoxaparin and tetraDOCA conjugate (EnoxaTD) was developed using end-site-specific chemical glycosylation [59].

\subsection{Heparin Conjugates for Anti-Cancer Therapy}

The study of the use of heparins or heparin derivatives in cancer treatment began recently, showing promising results in terms of their ability to treat several tumors [60]. Cancer is one of the leading causes of death worldwide, and some cancer patients receive UFH or LMWH to prevent cancer-associated thrombosis (CAT) or blood coagulation. The use of heparin in cancer patients has shown various therapeutic effects; thus, scientists have attempted to modify heparin's molecular structure to enhance its anti-cancer effects. In particular, heparin conjugates that have been chemically modified with other drugs or molecules have several advantages in terms of decreasing the bleeding toxicity of heparin as well as enhancing its biological activities. For example, when heparin binds to hydrophobic molecules such as cholesterol or bile acids, its anti-cancer effect can be increased along with a loss of its anticoagulant effect [61,62]. Various heparin and bile acid conjugates with taurocholic acid (TCA) or deoxycholic acid (DOCA) have been prepared and their ability proven, resulting in delayed tumor growth and metastasis [63,64]. Heparin-taurocholate conjugate (HT10) or heparin-DOCA conjugate (H-DOCA) were shown to inhibit tumor growth and metastasis while regulating the activity of tumor-related growth factors such as vascular endothelial growth factor A (VEGF A). VEGF A has a heparin-binding domain in its structure $[65,66]$. Recently, the target range of heparin derivatives was extended to tumor-related proteins such as transforming growth factor- $\beta 1$ (TGF- $\beta 1$ ), CXCL12, vascular endothelial growth factor C (VEGF C), and heparanase [67-69].

Heparin derivatives developed for anti-cancer treatment are not necessarily limited to heparin-steroid structures or derived from UFH. For example, PG545 is a heparin-like synthetic molecule with a hydrophobic cholestanyl aglycone moiety (Figure 3). It can show a strong anti-cancer effect, inhibiting angiogenic factors, with mild anticoagulant activity and stimulating immune responses against tumors [70-72]. Interestingly, it was recently reported that PG545 also displays potential for use as an anti-viral agent against SARS-CoV-2 and as a heparanase inhibitor with anti-lymphoma effects [73,74]. On the other hand, various function molecules such as tocopherol (for $\mathrm{pH}$-triggered polymeric micelles) [75], biotin (for anti-heparanase activity to treat multiple myeloma) [76], chlorambucil (as a redox-responsive prodrug) [77], suramin fragment (to enhance or mimic heparin's properties) [78,79], and the thiol group (for pH and GSH dual-responsive carriers for inhibiting tumor growth) [80] were recently conjugated to heparin molecules as new therapeutic biomolecules; they are currently under evaluation. In addition, heparin can be chemically modified with a hydrophobic photosensitizer (pyropheophorbide-a) for photodynamic therapy [81]. In a study, a polyethylene-glycol-modified (PEGylated) heparin and PDT conjugate achieved high tumor accumulation and had strong tumor-inhibitory 
effects. There was a complex study concerning the synthesis of a heparin derivative with matrix metalloproteinase (MMP2)-specific peptides for M2-to-M1-like macrophage reprogramming [82]. In the case of the heparin-peptide conjugate, heparin served not only as a hydrophilic biomaterial but also as a vessel for normalizing biomolecules contributing to anti-angiogenic effects. The results of studies conducted in animals showed that the heparin conjugate promoted potent tumor inhibition, anti-metastatic effects, and overall tumor microenvironment (TME) improvements. Taken together, heparin mimics, derivatives, and conjugates may be used in the design of efficacious and biocompatible therapeutics rather than unmodified heparins, as shown in Table 1.
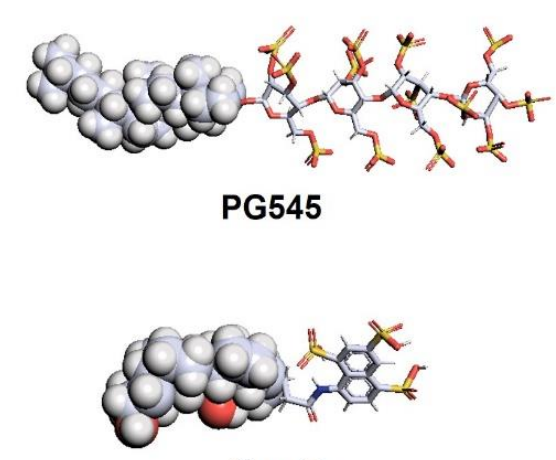

SuraD
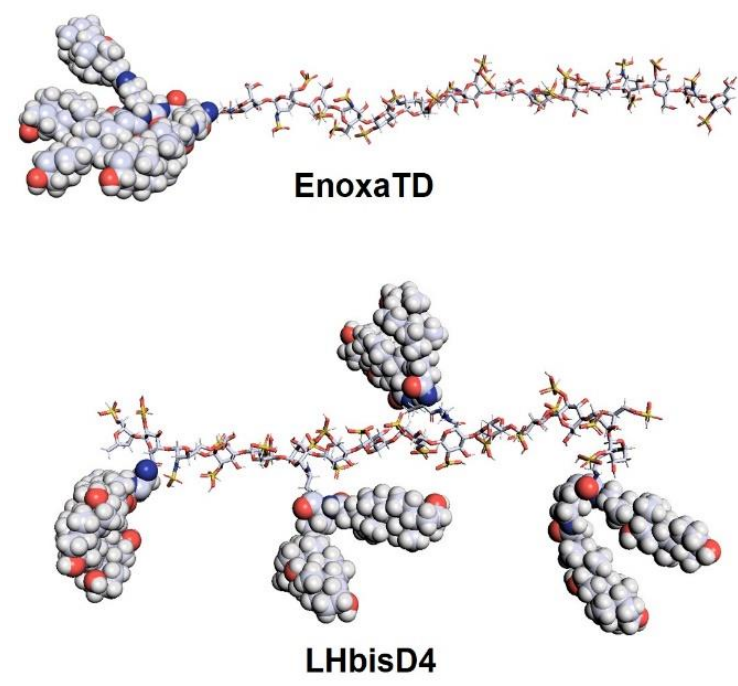
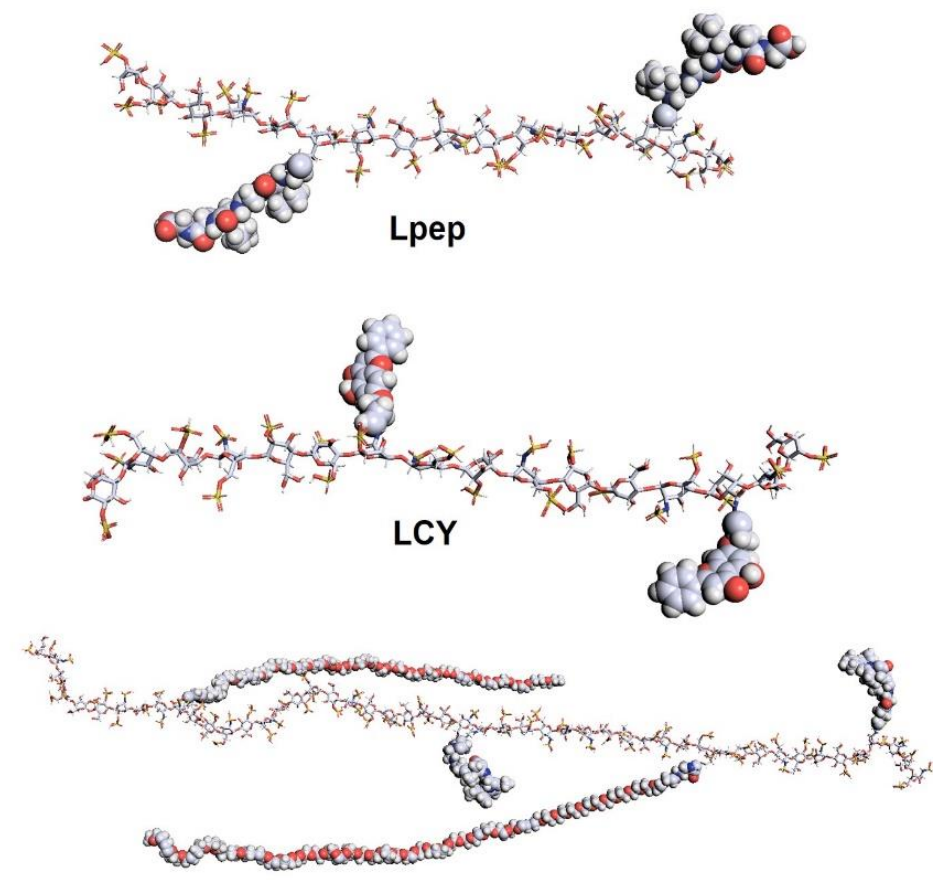

HP-Ppa-SS-mPEG

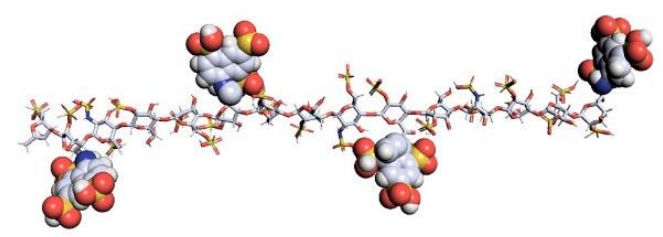

LHsura

Figure 3. Chemical structures of recently studied heparin conjugates and heparin-mimic biomolecules. Heparin or the heparin-mimic moiety in the molecule is expressed as a stick, while the conjugate is expressed as a sphere. The molecular structures were visualized using the PyMOL (the PyMOL Molecular Graphics System, Version 2.5.0, Schrödinger) program. SuraD, suramin fragment and deoxycholic acid conjugate; EnoxaTD, enoxaparin and TetraDOCA conjugate; LHbisD4, LMWH and bisDOCA conjugate; Lpep, LMWH and peptide conjugate; LCY, LMWH and chrysin conjugate; HP-Ppa-SS-mPEG, PEG-detachable pyropheophorbide-a (Ppa)-functionalized heparin; LHsura, LMWH, and suramin fragment conjugate. 
Table 1. Recently developed heparin-based biomolecules for the treatment of various diseases.

\begin{tabular}{|c|c|c|c|c|c|}
\hline Class & Molecular Effects & Materials & Highlight & Year & Refs. \\
\hline Heparin & Inhibits influenza H5N1 & $\begin{array}{l}\text { Chemically modified } \\
\text { heparin }\end{array}$ & $\begin{array}{l}\text { A H5 pseudotyped } \\
\text { HIV system }\end{array}$ & 2015 & [83] \\
\hline Heparin & Chronic kidney disease & Tinzaparin & $\begin{array}{l}\mathrm{CrCl} \geq 20 \mathrm{~mL} / \mathrm{min} \\
\text { in patients }\end{array}$ & 2019 & [84] \\
\hline Heparin & Transduction efficiency & Enoxaparin & $\begin{array}{l}\text { pLV-S }{ }^{1} \text { typed } \\
\text { virus }\end{array}$ & 2021 & [85] \\
\hline Heparin & Sepsis inhibition & LMWH & $\begin{array}{l}\text { Patients with } \\
\text { COVID-19 }\end{array}$ & 2020 & [86] \\
\hline Heparin & Coagulopathy in COVID-19 & LMWH & $\begin{array}{l}\text { Change in survival } \\
\text { rates }\end{array}$ & 2020 & [87] \\
\hline Heparin & Wound healing & Heparin & $\begin{array}{c}\text { Hemostatic } \\
\text { protein, VWF } \\
\text { deficiency }\end{array}$ & 2019 & [30] \\
\hline Synthetic molecule & Heparanase inhibitor & Pixatimod & $\begin{array}{l}\text { Directly binds to } \\
\text { S1 protein RBD of } \\
\text { SARS-CoV-2 }\end{array}$ & 2020 & [88] \\
\hline Synthetic molecule & Heparanase inhibitor & Roneparstat & Myeloma therapy & 2018 & [89] \\
\hline Nanocarrier & Hybrid nano-thin film & $\begin{array}{l}\text { Heparin/peptide- } \\
\text { polyethylene } \\
\text { glycol }\end{array}$ & Store morphogen & 2018 & [90] \\
\hline Nanocarrier & Anti-cancer activity & $\begin{array}{l}\text { AIB1 }{ }^{3} \text { siRNA-loaded } \\
\text { PEI/heparin } / \mathrm{Ca}^{2+} \mathrm{NPs}\end{array}$ & $\begin{array}{l}\text { A non-viral } \\
\text { polymer carrier for } \\
\text { AIB1 siRNA }\end{array}$ & 2018 & [91] \\
\hline Nanocarrier & Anti-thrombotic & $\begin{array}{l}\text { Hp-DOCA-PVAX } \\
\text { nanocomposite }\end{array}$ & $\begin{array}{c}\text { Reduced } \\
\text { inflammation and } \\
\text { coagulation }\end{array}$ & 2019 & [92] \\
\hline Nanocarrier & Malaria therapy & $\begin{array}{c}\text { Artesunate-heparin } \\
\text { conjugate-based } \\
\text { nano-capsules }\end{array}$ & $\begin{array}{l}\text { P. falciparum } \\
\text { inhibition }\end{array}$ & 2019 & [93] \\
\hline Nanocarrier & Photodynamic therapy & Hp-Ppa-SS-mPEG ${ }^{5}$ & $\begin{array}{c}\text { Increased ROS } \\
\text { production and } \\
\text { apoptosis }\end{array}$ & 2021 & [81] \\
\hline Nanocarrier & $\begin{array}{l}\text { Human colon } \\
\text { adenocarcinoma }\end{array}$ & $\begin{array}{l}\text { Chitosan/heparin } \\
\text { polyelectrolyte complexes }\end{array}$ & $\begin{array}{l}\text { Oral hydrophilic } \\
\text { drugs }\end{array}$ & 2021 & [94] \\
\hline Nanocarrier & $\begin{array}{c}\text { Anti-tumor and } \\
\text { anti-angiogenic efficacy }\end{array}$ & $\begin{array}{l}\text { Dalteparin-Poloxamer with } \\
\text { LR-DOX }{ }^{6} \text { hydrogel }\end{array}$ & $\begin{array}{l}\text { Exhibiting a good } \\
\text { thermosensitivity }\end{array}$ & 2019 & [95] \\
\hline Conjugate & Heparanase & With biotin & $\begin{array}{l}\text { Metastasis } \\
\text { inhibition }\end{array}$ & 2020 & [96] \\
\hline Conjugate & $\begin{array}{l}\text { Anti-tumor and } \\
\text { anti-angiogenic efficacy }\end{array}$ & $\begin{array}{c}\text { PEG- } \\
\text { LHT7/TRAIL/protamine } \\
\text { nanocomplex }\end{array}$ & $\begin{array}{l}\text { Increased } \\
\text { tumor-resident } \\
\text { time for TRAIL }\end{array}$ & 2021 & [97] \\
\hline Conjugate & Anti-angiogenic activity & Suramin fragment-DOCA & $\begin{array}{l}\text { Binding with HBD } \\
7 \text { of VEGF } \\
8\end{array}$ & 2021 & [78] \\
\hline Conjugate & $\begin{array}{c}\text { GAG }^{9} \text {-based COVID-19 } \\
\text { therapeutics }\end{array}$ & $\begin{array}{l}\text { Heparin-amine--PEG }{ }_{3}^{-} \\
\text {biotin }\end{array}$ & $\begin{array}{l}\text { SARS-CoV-2 } \\
\text { glycoprotein } \\
\text { binding }\end{array}$ & 2020 & [98] \\
\hline
\end{tabular}


Table 1. Cont.

\begin{tabular}{|c|c|c|c|c|c|}
\hline Class & Molecular Effects & Materials & Highlight & Year & Refs. \\
\hline Conjugate & Anti-cancer activity & Heparin-chlorambucil & $\begin{array}{l}\text { High redox } \\
\text { potential. }\end{array}$ & 2019 & [77] \\
\hline Conjugate & Anti-cancer activity & $\begin{array}{l}\text { Heparin- } \alpha \text {-tocopherol- } \\
\text { docetaxel }\end{array}$ & $\begin{array}{c}\text { Increased } \\
\text { cytotoxicity against } \\
\text { cancer cells }\end{array}$ & 2020 & [75] \\
\hline Conjugate & Protein interactions & Biotin-heparin & At low temperature & 2018 & [99] \\
\hline Conjugate & Anti-cancer activity & Heparin-SH-doxorubicin & $\begin{array}{c}\text { High } \\
\text { biocompatibility }\end{array}$ & 2020 & [80] \\
\hline Conjugate & $\begin{array}{l}\text { Improved anti-angiogenic } \\
\text { activity }\end{array}$ & ES2-GSHP 11 & $\begin{array}{l}\text { Wide } \mathrm{pH} \text { activity } \\
\text { range and a longer } \\
\text { half-life }\end{array}$ & 2019 & [100] \\
\hline Conjugate & Anti-cancer activity & $\begin{array}{l}\text { PCLA-PEG-PCLA }{ }^{12} \\
\text { polymeric hydrogel }\end{array}$ & $\begin{array}{l}\text { Temperature- } \\
\text { responsive } \\
\text { hydrogel }\end{array}$ & 2019 & [101] \\
\hline Conjugate & $\begin{array}{c}\text { Anti-corneal } \\
\text { neovascularization }\end{array}$ & LMWH & $\begin{array}{c}\text { Distribution level } \\
\text { needs every } 4 \text { to } 6 \mathrm{~h}\end{array}$ & 2018 & [102] \\
\hline Conjugate & Anti-microbial activity & Piscidin-heparin & $\mathrm{Cu}^{2+}$ interaction & 2018 & [103] \\
\hline
\end{tabular}

\subsection{Heparins as Anti-Viral Agents}

Various anti-viral effects of heparin-based biomolecules were demonstrated in a recent study. In the case of influenza, a common flu virus, it is reported that heparin and heparin derivatives can have preventative effects through inhibiting the ability of the H5N1 strain of the virus to attach to cells [83]. This means that heparin derivatives and conjugates may be a potential source of viral inhibitors. In terms of recent world events, coronavirus disease 2019 (COVID-19) grabbed the attention of researchers focusing on advanced medication systems. Heparin treatment for COVID-19 patients has therapeutic potential; however, the exact role of heparin needs to be proven [104]. Some research has shown, in vitro, that heparin has promising anti-viral activity for the inhibition of SARS-CoV-2 (severe acute respiratory syndrome-related coronavirus-2) [105]. Another report has suggested that the administration of heparin to COVID-19 patients might be associated with lower mortality [87]. The use of heparins in COVID-19 patients may be safe; however, further clinical studies are needed to prove their therapeutic effect [106]. Regarding the use of heparins as anti-viral agents, it seems that UFH has stronger antiviral activity than LMWHs, inhibiting spike proteins in SARS-CoV-2 [107]. In addition, new anti-viral effects of heparin derivatives such as PG545, which were initially developed as anti-cancer drugs, have also been reported [74]. On the other hand, in response to the COVID-19 pandemic, the US Food and Drug Administration (FDA) recently decided to allow the use of a medical device named Seraph R100 that has heparin molecules on its surface for reducing bloodstream pathogens [108]. The surface of the heparin is designed to bond with the existing virus and remove it from the blood. These studies indirectly show that heparin may have value as a probe as well as a therapeutic agent. The development of heparin-utilizing devices or heparin derivatives for anti-viral effects might continue based on their protein binding and anti-viral ability. 


\section{Recent Nanoformulation of Heparin}

The use of nanoformulations of heparin or heparin derivatives for the treatment of various diseases has been shown to have several advantages [109]. Nanoformulations of drugs usually have several advantages, such as targeting effects, increased circulation times, and higher efficiency [110-112]. In the case of heparin, which is a highly hydrophilic biomolecule, the formation of nanoparticles is mainly achieved though the binding of hydrophobic organic molecules (Figure 4) [113]. For example, most heparin conjugates, including heparin-DOCA conjugates and bisdeoxycholyl-heparin (LHbisD4), which was developed to enhance oral absorption, can generate nanoparticles via self-assembly $[114,115]$. The redox-responsive heparin-chlorambucil conjugate that was recently developed by Andrgie et al., the heparin-biotin conjugates developed by Esposito et al., and the heparinpyropheophorbide conjugate developed by $\mathrm{Wu}$ et al. can also self-assemble into spherical nanoparticles in an aqueous solvent $[76,77]$. Heparin conjugates are sometimes mixed with other polymers such as their antidote (protamine sulfate) $[116,117]$ or anti-inflammatory polymer (copolyoxalate containing vanillyl alcohol, PVAX) [92] via co-assembly to increase the function and retention time of heparin in the blood, thus reducing its side effects on hemostasis. Heparin based on functional nanomaterials can be utilized for the treatment of various diseases. For example, Wan et al. recently conjugated poly( $\varepsilon$-caprolactone) (PCL) and keratin with heparin to bind VEGF [118]. Heparin/VEGF engineered materials show good biocompatibility upon testing for blood clotting time, hemolysis, and platelet adhesion. Taken together, it can be observed that there are many heparin-based nanoparticles that bear interesting characteristics for use in medical treatment. Considering the development of nanotechnology and heparin-based biomolecules, nanoformulations of heparin should be further studied in the future.

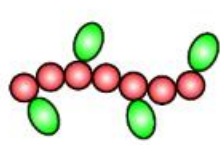

H-DOCA
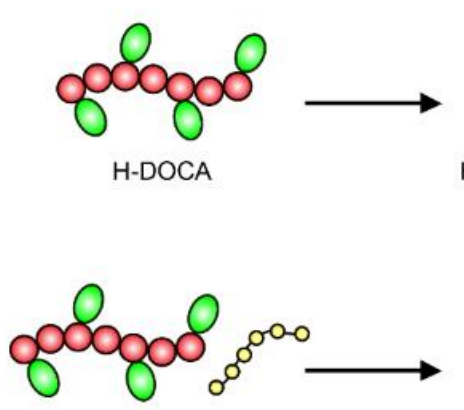

H-DOCA PVAX

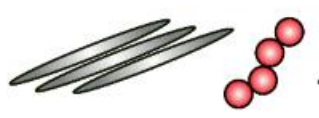

PCL/Keratin mats Heparin
H-DOCA Nanoparticle
HDP Nanoparticle
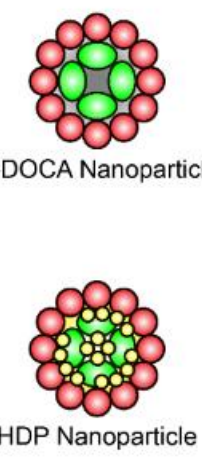

-

PCL/Keratin-Heparin Nano-biocomposite mats

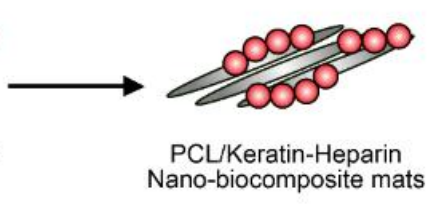

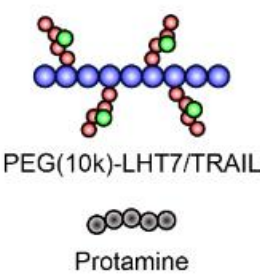
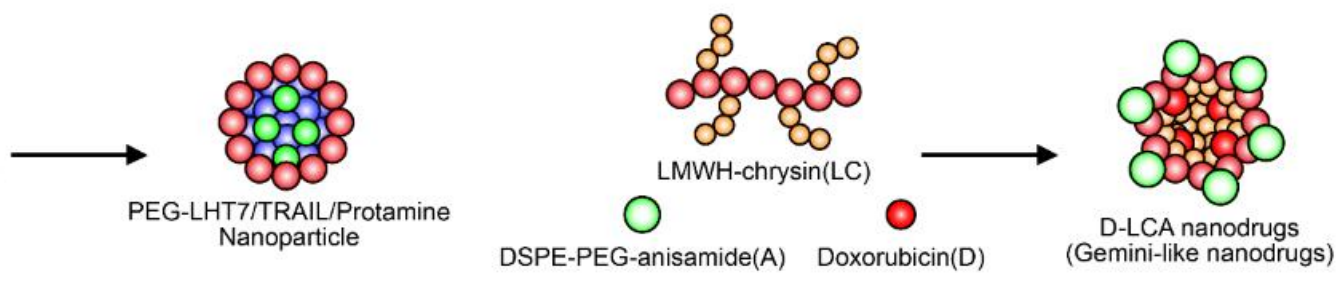

Figure 4. The schematic structures of nanoparticles based on heparin derivatives. Different types of heparin conjugates are currently being investigated as nanodrug carriers or new drug candidates. The self-assembled heparin-drug conjugate that forms after nanoformulation has shown great therapeutic potential for use in various therapies. 


\section{Conclusions and Perspectives}

Heparin and heparin derivatives have shown great therapeutic potential as anticoagulants or functional biomolecules in many polysaccharide studies. However, the clinical use of heparin for the treatment of thromboembolism or atrial fibrillation has been challenged with the advent of DOACs such as rivaroxaban and apixaban. Although heparins including UFH and LMWHs are highly safe and effective, their use in the clinic is limited to parenteral administration due to their poor oral bioavailability. Considering the importance of anticoagulants for use in prophylaxis, it is highly advantageous that DOACs can be taken orally every day $[33,119]$. Therefore, although the increasing use of DOACs is inevitable, both heparins and DOACs will likely be widely used clinically because of the unique safety profile and effectiveness of heparin [120-124]. On the other hand, research on the non-coagulant effects of heparin based on their therapeutic potential in various clinical situations is ongoing. Due to the other functional properties of UFH and LMWH observed, they have been utilized for applications besides being used as anticoagulants [125]. Many preclinical studies and experimental research papers have shown that heparin can be considered a modulator of growth factors, cell-adhesion molecules, chemokines, viral proteins, immune factors, and endothelial cells [42,126-128]. Even without the anticoagulant effect of heparin, it is clear that its number of new applications seems set to increase in the near future.

In this review, we propose that chemical modification or conjugation with heparin molecules can improve the use of heparin as a therapeutic in various diseases. These approaches might be able to greatly expand the current treatment options for heparins in clinical settings with high efficacy and low toxicity, overcoming the current limitations of their clinical application as anticoagulants. In this regard, several studies have evaluated and clinically analyzed the therapeutic functions of various heparin-based biomolecules. Recent advances in the preparation of heparin-related biomolecules or nanoformulations of heparin conjugates include the emergence of heparin derivatives or conjugates that are suitable for successful clinical applications. In this article, we summarized the recent advances in the development of heparin derivatives and conjugates as potential therapeutics. Considering the current limitations of the use of heparin, we expect that new heparin derivatives and conjugates will provide us with opportunities for further clinical applications.

Author Contributions: Conceptualization, J.P.; visualization, S.-B.Y. and J.P., writing—original draft, N.B., S.-B.Y. and J.P.; writing-review and editing, T.-B.K., J.-H.L. and J.P.; funding acquisition, J.P. All authors have read and agreed to the published version of the manuscript.

Funding: This paper was supported by Konkuk University in 2021.

Institutional Review Board Statement: Not applicable.

Informed Consent Statement: Not applicable.

Data Availability Statement: Not applicable.

Conflicts of Interest: The authors declare no conflict of interest.

\section{References}

1. Rabenstein, D.L. Heparin and heparan sulfate: Structure and function. Nat. Prod. Rep. 2002, 19, 312-331. [CrossRef] [PubMed]

2. Prydz, K. Determinants of Glycosaminoglycan (GAG) Structure. Biomolecules 2015, 5, 2003-2022. [CrossRef] [PubMed]

3. Hacker, U.; Nybakken, K.; Perrimon, N. Heparan sulphate proteoglycans: The sweet side of development. Nat. Rev. Mol. Cell Biol. 2005, 6, 530-541. [CrossRef] [PubMed]

4. Veraldi, N.; Zouggari, N.; de Agostini, A. The challenge of modulating heparan sulfate turnover by multitarget heparin derivatives. Molecules 2020, 25, 390. [CrossRef] [PubMed]

5. De Pasquale, V.; Pavone, L.M. Heparan sulfate proteoglycan signaling in tumor microenvironment. Int. J. Mol. Sci. 2020, $21,6588$. [CrossRef] [PubMed] 
6. Kaczor-Kaminska, M.; Stalinska, K.; Kaminski, K.; Pisarek, A.; Maziarz, U.; Feldman, A.; Wrobel, M. Murine cellular model of mucopolysaccharidosis, type lllB (MPS llB)-Apreliminary study with particular emphasis on the non-oxidative L-cysteine metabolism. Biochimie 2020, 174, 84-94. [CrossRef]

7. Hao, C.; Sun, M.J.; Wang, H.M.; Zhang, L.J.; Wang, W. Low molecular weight heparins and their clinical applications. Prog. Mol. Biol. Transl. 2019, 163, 21-39.

8. Sarantis, P.; Bokas, A.; Papadimitropoulou, A.; Koustas, E.; Theocharis, S.; Papakotoulas, P.; Schizas, D.; Papalampros, A.; Felekouras, E.; Papavassiliou, A.G.; et al. Combinatorial treatment of tinzaparin and chemotherapy can induce a significant antitumor effect in pancreatic cancer. Int. J. Mol. Sci. 2021, 22. [CrossRef]

9. Kalaska, B.; Kaminski, K.; Miklosz, J.; Nakai, K.; Yusa, S.-I.; Pawlak, D.; Szczubialka, K. Anticoagulant properties of poly (sodium 2-(acrylamido)-2-methylpropanesulfonate)-based di- and triblock polymers. Biomolecules 2018, 19, 3104-3118. [CrossRef]

10. Cosmi, B.; Palareti, G. Old and new heparins. Thromb. Res. 2012, 129, 388-391. [CrossRef]

11. Mohamed, S.; Coombe, D.R. Heparin Mimetics: Their Therapeutic Potential. Pharmaceuticals 2017, 10, 78. [CrossRef]

12. Gray, E.; Mulloy, B.; Barrowcliffe, T.W. Heparin and low-molecular-weight heparin. Thromb. Haemost 2008, 99, 807-818.

13. Du, S.; Yu, Y.; Xu, C.; Xiong, H.; Yang, S.; Yao, J. LMWH and its derivatives represent new rational for cancer therapy: Construction strategies and combination therapy. Drug Discov. Today 2019, 24, 2096-2104. [CrossRef]

14. Berdiaki, A.; Neagu, M.; Giatagana, E.M.; Kuskov, A.; Tsatsakis, A.M.; Tzanakakis, G.N.; Nikitovic, D. Glycosaminoglycans: Carriers and targets for tailored anti-cancer therapy. Biomolecules 2021, 11, 395. [CrossRef]

15. Bokas, A.; Papakotoulas, P.; Sarantis, P.; Papadimitropoulou, A.; Papavassiliou, A.G.; Karamouzis, M.V. Mechanisms of the Antitumor Activity of Low Molecular Weight Heparins in Pancreatic Adenocarcinomas. Cancers 2020, 12, 432. [CrossRef]

16. Ejaz, U.; Akhtar, F.; Xue, J.; Wan, X.; Zhang, T.; He, S. Review: Inhibitory potential of low molecular weight Heparin in cell adhesion; emphasis on tumor metastasis. Eur. J. Pharmacol. 2021, 892, 173778. [CrossRef] [PubMed]

17. Shriver, Z.; Sundaram, M.; Venkataraman, G.; Fareed, J.; Linhardt, R.; Biemann, K.; Sasisekharan, R. Cleavage of the antithrombin III binding site in heparin by heparinases and its implication in the generation of low molecular weight heparin. Proc. Natl. Acad. Sci. USA 2000, 97, 10365-10370. [CrossRef] [PubMed]

18. Kim, J.; Gearhart, M.M.; Zurick, A.; Zuccarello, M.; James, L.; Luchette, F.A. Preliminary report on the safety of heparin for deep venous thrombosis prophylaxis after severe head injury. J. Trauma 2002, 53, 38-42. [CrossRef] [PubMed]

19. Hirsh, J.; Warkentin, T.E.; Raschke, R.; Granger, C.; Ohman, E.M.; Dalen, J.E. Heparin and low-molecular-weight heparin: Mechanisms of action, pharmacokinetics, dosing considerations, monitoring, efficacy, and safety. Chest 1998, 114, 489S-510S. [CrossRef] [PubMed]

20. Fang, G.H.; Tang, B. Advanced delivery strategies facilitating oral absorption of heparins. Asian J. Pharm. Sci. 2020, 15, 449-460. [CrossRef] [PubMed]

21. Schluter, A.; Lamprecht, A. Current Developments for the Oral Delivery of Heparin. Curr. Pharm. Biotechnol. 2014, 15, 640-649. [CrossRef]

22. Goldberg, M.; Gomez-Orellana, I. Challenges for the oral delivery of macromolecules. Nat. Rev. Drug Discov. 2003, 2, 289-295. [CrossRef] [PubMed]

23. Pernod, G.; Joly, M.; Sonnet, B. Direct oral anticoagulant (DOAC) versus low-molecular-weight heparin (LMWH) for the treatment of cancer-associated thrombosis (which agent for which patient). J. Med. Vasc. 2020, 45, 6S17-6S23. [PubMed]

24. Costin, J.; Ansell, J.; Bakhru, S.; Laulicht, B.; Steiner, S. The new oral anticoagulants: Clinical use and reversal agent development. ISBT Sci. Ser. 2015, 10, 324-331. [CrossRef]

25. Lazo-Langner, A.; Fleet, J.L.; McArthur, E.; Garg, A.X. Rivaroxaban vs. low molecular weight heparin for the prevention of venous thromboembolism after hip or knee arthroplasty: A cohort study. J. Thromb. Haemost. 2014, 12, 1626-1635. [CrossRef]

26. Yang, X.; Du, H.; Liu, J.; Zhai, G. Advanced nanocarriers based on heparin and its derivatives for cancer management. Biomolecules 2015, 16, 423-436. [CrossRef]

27. Kakkar, A.K.; Levine, M.N.; Kadziola, Z.; Lemoine, N.R.; Low, V.; Patel, H.K.; Rustin, G.; Thomas, M.; Quigley, M.; Williamson, R.C. Low molecular weight heparin, therapy with dalteparin, and survival in advanced cancer: The fragmin advanced malignancy outcome study (FAMOUS). J. Clin. Oncol. 2004, 22, 1944-1948. [CrossRef]

28. Icli, F.; Akbulut, H.; Utkan, G.; Yalcin, B.; Dincol, D.; Isikdogan, A.; Demirkazik, A.; Onur, H.; Cay, F.; Buyukcelik, A. Low molecular weight heparin (LMWH) increases the efficacy of cisplatinum plus gemcitabine combination in advanced pancreatic cancer. J. Surg. Oncol. 2007, 95, 507-512. [CrossRef]

29. Altinbas, M.; Coskun, H.S.; Er, O.; Ozkan, M.; Eser, B.; Unal, A.; Cetin, M.; Soyuer, S. A randomized clinical trial of combination chemotherapy with and without low-molecular-weight heparin in small cell lung cancer. J. Thromb. Haemost. 2004, 2, $1266-1271$. [CrossRef]

30. Ishihara, J.; Ishihara, A.; Starke, R.D.; Peghaire, C.R.; Smith, K.E.; McKinnon, T.A.J.; Tabata, Y.; Sasaki, K.; White, M.J.V.; Fukunaga, K.; et al. The heparin binding domain of von Willebrand factor binds to growth factors and promotes angiogenesis in wound healing. Blood 2019, 133, 2559-2569. [CrossRef]

31. Mulloy, B. The non-anticoagulant promise of heparin and its mimetics. Curr. Opin. Pharmacol. 2019, 46, 50-54. [CrossRef]

32. Wat, J.M.; Hawrylyshyn, K.; Baczyk, D.; Greig, I.R.; Kingdom, J.C. Effects of glycol-split low molecular weight heparin on placental, endothelial, and anti-inflammatory pathways relevant to preeclampsia. Biol. Reprod. 2018, 99, 1082-1090. [CrossRef]

33. Park, J.; Byun, Y. Recent advances in anticoagulant drug delivery. Exp. Opin. Drug Deliv. 2016, 13, 421-434. [CrossRef] 
34. Johnson, D.J.; Li, W.; Adams, T.E.; Huntington, J.A. Antithrombin-S195A factor Xa-heparin structure reveals the allosteric mechanism of antithrombin activation. EMBO J. 2006, 25, 2029-2037. [CrossRef] [PubMed]

35. Linhardt, R.J.; Gunay, N.S. Production and chemical processing of low molecular weight heparins. Semin. Thromb. Hemost. 1999, 25, 5-16. [PubMed]

36. Nishino, T.; Aizu, Y.; Nagumo, T. The influence of sulfate content and molecular weight of a fucan sulfate from the brown seaweed Ecklonia Kurome on its antithrombin activity. Thromb. Res. 1991, 64, 723-731. [CrossRef]

37. Ingle, R.G.; Agarwal, A.S. A world of low molecular weight heparins (LMWHs) enoxaparin as a promising moiety-A review. Carbohydr. Polym. 2014, 106, 148-153. [CrossRef] [PubMed]

38. Khan, S.; Gor, J.; Mulloy, B.; Perkins, S.J. Semi-rigid solution structures of heparin by constrained X-ray scattering modelling: New insight into heparin-protein complexes. J. Mol. Biol. 2010, 395, 504-521. [CrossRef] [PubMed]

39. Wang, T.; Liu, L.; Voglmeir, J. Chemoenzymatic synthesis of ultralow and low-molecular weight heparins. BBA Proteins Proteom. 2020, 1868, 140301. [CrossRef]

40. Viskov, C.; Just, M.; Laux, V.; Mourier, P.; Lorenz, M. Description of the chemical and pharmacological characteristics of a new hemisynthetic ultra-low-molecular-weight heparin, AVE5026. J. Thromb. Haemost. 2009, 7, 1143-1151. [CrossRef]

41. Decousus, H.; Prandoni, P.; Mismetti, P.; Bauersachs, R.M.; Boda, Z.; Brenner, B.; Laporte, S.; Matyas, L.; Middeldorp, S.; Sokurenko, G.; et al. Fondaparinux for the treatment of superficial-vein thrombosis in the legs. N. Engl. J. Med. 2010, 363, 1222-1232. [CrossRef]

42. Capila, I.; Linhardt, R.J. Heparin-protein interactions. Angew. Chem. Int. Ed. Engl. 2002, 41, 391-412. [CrossRef]

43. Ciccone, M.M.; Cortese, F.; Corbo, F.; Corrales, N.E.; Al-Momen, A.K.; Silva, A.; Zito, A.; Pinto, M.; Gesualdo, M.; Scicchitano, P. Bemiparin, an effective and safe low molecular weight heparin: A review. Vasc. Pharmacol. 2014, 62, 32-37. [CrossRef]

44. Agnelli, G.; George, D.J.; Kakkar, A.K.; Fisher, W.; Lassen, M.R.; Mismetti, P.; Mouret, P.; Chaudhari, U.; Lawson, F.; Turpie, A.G.; et al. Semuloparin for thromboprophylaxis in patients receiving chemotherapy for cancer. N. Engl. J. Med. 2012, 366, 601-609. [CrossRef]

45. Bauer, K.A. Fondaparinux sodium: A selective inhibitor of factor Xa. Am. J. Health Syst. Pharm. 2001, 58, S14-S17. [CrossRef] [PubMed]

46. Zhang, Y.R.; Zhang, M.; Tan, L.J.; Pan, N.N.; Zhang, L.J. The clinical use of Fondaparinux: A synthetic heparin pentasaccharide. Prog. Mol. Biol. Transl. 2019, 163, 41-53.

47. McRae, H.L.; Militello, L.; Refaai, M.A. Updates in anticoagulation therapy monitoring. Biomedicines 2021, 9, 262. [CrossRef] [PubMed]

48. Arbit, E.; Goldberg, M.; Gomez-Orellana, I.; Majuru, S. Oral heparin: Status review. Thromb. J. 2006, 4, 6. [CrossRef]

49. Salartash, K.; Gonze, M.D.; Leone-Bay, A.; Baughman, R.; Sternbergh, W.C., 3rd; Money, S.R. Oral low-molecular weight heparin and delivery agent prevents jugular venous thrombosis in the rat. J. Vasc. Surg. 1999, 30, 526-531. [CrossRef]

50. Baughman, R.A.; Kapoor, S.C.; Agarwal, R.K.; Kisicki, J.; Catella-Lawson, F.; FitzGerald, G.A. Oral delivery of anticoagulant doses of heparin. A randomized, double-blind, controlled study in humans. Circulation 1998, 98, 1610-1615. [CrossRef] [PubMed]

51. Salartash, K.; Lepore, M.; Gonze, M.D.; Leone-Bay, A.; Baughman, R.; Sternbergh, W.C., 3rd; Bowen, J.C.; Money, S.R. Treatment of experimentally induced caval thrombosis with oral low molecular weight heparin and delivery agent in a porcine model of deep venous thrombosis. Ann. Surg. 2000, 231, 789-794. [CrossRef]

52. Hull, R.D.; Kakkar, A.K.; Marder, V.J.; Pineo, G.F.; Goldberg, M.M.; Raskob, G.E.; Trial, P. Oral SNAC-heparin vs. enoxaparin for preventing venous thromboembolism following total hip replacement. Blood 2002, 100, 148a-149a. [CrossRef]

53. Kim, S.K.; Vaishali, B.; Lee, E.; Lee, S.; Lee, Y.K.; Kumar, T.S.; Moon, H.T.; Byun, Y. Oral delivery of chemical conjugates of heparin and deoxycholic acid in aqueous formulation. Thromb. Res. 2006, 117, 419-427. [CrossRef]

54. Park, J.W.; Jeon, O.C.; Kim, S.K.; Al-Hilal, T.A.; Lim, K.M.; Moon, H.T.; Kim, C.Y.; Byun, Y. Pharmacokinetic evaluation of an oral tablet form of low-molecular-weight heparin and deoxycholic acid conjugate as a novel oral anticoagulant. Thromb. Haemost. 2011, 105, 1060-1071. [CrossRef]

55. Paliwal, R.; Paliwal, S.R.; Agrawal, G.P.; Vyas, S.P. Biomimetic solid lipid nanoparticles for oral bioavailability enhancement of low molecular weight heparin and its lipid conjugates: In vitro and in vivo evaluation. Mol. Pharm. 2011, 8, 1314-1321. [CrossRef]

56. Park, J.W.; Jeon, O.C.; Kim, S.K.; Al-Hilal, T.A.; Moon, H.T.; Kim, C.Y.; Byun, Y. Anticoagulant efficacy of solid oral formulations containing a new heparin derivative. Mol. Pharm. 2010, 7, 836-843. [CrossRef] [PubMed]

57. Hwang, S.R.; Seo, D.H.; Al-Hilal, T.A.; Jeon, O.C.; Kang, J.H.; Kim, S.H.; Kim, H.S.; Chang, Y.T.; Kang, Y.M.; Yang, V.C.; et al. Orally active desulfated low molecular weight heparin and deoxycholic acid conjugate, 6ODS-LHbD, suppresses neovascularization and bone destruction in arthritis. J. Control. Release 2012, 163, 374-384. [CrossRef]

58. Khatun, Z.; Nurunnabi, M.; Cho, K.J.; Byun, Y.; Bae, Y.H.; Lee, Y.K. Oral absorption mechanism and anti-angiogenesis effect of taurocholic acid-linked heparin-docetaxel conjugates. J. Control. Release 2014, 177C, 64-73. [CrossRef] [PubMed]

59. Park, J.; Jeon, O.C.; Yun, J.; Nam, H.; Hwang, J.; Al-Hilal, T.A.; Kim, K.; Kim, K.; Byun, Y. End-site-specific conjugation of enoxaparin and tetradeoxycholic acid using nonenzymatic glycosylation for oral delivery. J. Med. Chem. 2016, 59, 10520-10529. [CrossRef] [PubMed]

60. Atallah, J.; Khachfe, H.H.; Berro, J.; Assi, H.I. The use of heparin and heparin-like molecules in cancer treatment: A review. Cancer Treat. Res. Commun. 2020, 24, 100192. [CrossRef] [PubMed] 
61. Park, J.W.; Jeon, O.C.; Kim, S.K.; Al-Hilal, T.A.; Jin, S.J.; Moon, H.T.; Yang, V.C.; Kim, S.Y.; Byun, Y. High antiangiogenic and low anticoagulant efficacy of orally active low molecular weight heparin derivatives. J. Control. Release 2010, 148, 317-326. [CrossRef]

62. Park, K.; Lee, G.Y.; Kim, Y.S.; Yu, M.; Park, R.W.; Kim, I.S.; Kim, S.Y.; Byun, Y. Heparin-deoxycholic acid chemical conjugate as an anticancer drug carrier and its antitumor activity. J. Control. Release 2006, 114, 300-306. [CrossRef]

63. Lee, E.; Kim, Y.S.; Bae, S.M.; Kim, S.K.; Jin, S.; Chung, S.W.; Lee, M.; Moon, H.T.; Jeon, O.C.; Park, R.W.; et al. Polyproline-type helical-structured low-molecular weight heparin (LMWH)-taurocholate conjugate as a new angiogenesis inhibitor. Int. J. Cancer 2009, 124, 2755-2765. [CrossRef]

64. Bae, S.M.; Kim, J.H.; Chung, S.W.; Byun, Y.; Kim, S.Y.; Lee, B.H.; Kim, I.S.; Park, R.W. An apoptosis-homing peptide-conjugated low molecular weight heparin-taurocholate conjugate with antitumor properties. Biomaterials 2013, 34, 2077-2086. [CrossRef]

65. Fairbrother, W.J.; Champe, M.A.; Christinger, H.W.; Keyt, B.A.; Starovasnik, M.A. Solution structure of the heparin-binding domain of vascular endothelial growth factor. Struct. Fold. Des. 1998, 6, 637-648. [CrossRef]

66. Zhao, W.; McCallum, S.A.; Xiao, Z.; Zhang, F.; Linhardt, R.J. Binding affinities of vascular endothelial growth factor (VEGF) for heparin-derived oligosaccharides. Biosci. Rep. 2012, 32, 71-81. [CrossRef]

67. Cassinelli, G.; Torri, G.; Naggi, A. Non-Anticoagulant Heparins as Heparanase Inhibitors. Adv. Exp. Med. Biol. 2020, 1221, 493-522. [PubMed]

68. Choi, J.U.; Chung, S.W.; Al-Hilal, T.A.; Alam, F.; Park, J.; Mahmud, F.; Jeong, J.H.; Kim, S.Y.; Byun, Y. A heparin conjugate, LHbisD4, inhibits lymphangiogenesis and attenuates lymph node metastasis by blocking VEGF-C signaling pathway. Biomaterials 2017, 139, 56-66. [CrossRef]

69. Alam, F.; Al-Hilal, T.A.; Park, J.; Choi, J.U.; Mahmud, F.; Jeong, J.H.; Kim, I.S.; Kim, S.Y.; Hwang, S.R.; Byun, Y. Multi-stage inhibition in breast cancer metastasis by orally active triple conjugate, LHTD4 (low molecular weight heparin-taurocholatetetrameric deoxycholate). Biomaterials 2016, 86, 56-67. [CrossRef] [PubMed]

70. Dredge, K.; Hammond, E.; Handley, P.; Gonda, T.J.; Smith, M.T.; Vincent, C.; Brandt, R.; Ferro, V.; Bytheway, I. PG545, a dual heparanase and angiogenesis inhibitor, induces potent anti-tumour and anti-metastatic efficacy in preclinical models. Br. J. Cancer 2011, 104, 635-642. [CrossRef] [PubMed]

71. Dredge, K.; Brennan, T.V.; Hammond, E.; Lickliter, J.D.; Lin, L.; Bampton, D.; Handley, P.; Lankesheer, F.; Morrish, G.; Yang, Y.; et al. A Phase I study of the novel immunomodulatory agent PG545 (pixatimod) in subjects with advanced solid tumours. Br. J. Cancer 2018, 118, 1035-1041. [CrossRef]

72. Hoffmann, R.; Sarkar Bhattacharya, S.; Roy, D.; Winterhoff, B.; Schmidmaier, R.; Dredge, K.; Hammond, E.; Shridhar, V. Sulfated glycolipid PG545 induces endoplasmic reticulum stress and augments autophagic flux by enhancing anticancer chemotherapy efficacy in endometrial cancer. Biochem. Pharmacol. 2020, 178, 114003. [CrossRef]

73. Hammond, E.; Dredge, K. Heparanase Inhibition by Pixatimod (PG545): Basic Aspects and Future Perspectives. Adv. Exp. Med. Biol. 2020, 1221, 539-565.

74. Modhiran, N.; Gandhi, N.S.; Wimmer, N.; Cheung, S.; Stacey, K.; Young, P.R.; Ferro, V.; Watterson, D. Dual targeting of dengue virus virions and NS1 protein with the heparan sulfate mimic PG545. Antiviral. Res. 2019, 168, 121-127. [CrossRef]

75. Emami, J.; Kazemi, M.; Hasanzadeh, F.; Minaiyan, M.; Mirian, M.; Lavasanifar, A. Novel pH-triggered biocompatible polymeric micelles based on heparin-alpha-tocopherol conjugate for intracellular delivery of docetaxel in breast cancer. Pharm. Dev. Technol. 2020, 25, 492-509. [CrossRef] [PubMed]

76. Esposito, E.; Vlodavsky, I.; Barash, U.; Roscilli, G.; Milazzo, F.M.; Giannini, G.; Naggi, A. Novel N-acetyl-Glycol-split heparin biotin-conjugates endowed with anti-heparanase activity. Eur. J. Med. Chem. 2020, 186, 111831. [CrossRef] [PubMed]

77. Andrgie, A.T.; Birhan, Y.S.; Mekonnen, T.W.; Hanurry, E.Y.; Darge, H.F.; Lee, R.H.; Chou, H.Y.; Tsai, H.C. Redox-responsive heparin-chlorambucil conjugate polymeric prodrug for improved anti-tumor activity. Polymers 2019, 12, 43. [CrossRef]

78. Park, J.; Kang, T.B.; Lim, J.H.; Won, H.S. Molecular targeting of VEGF with a suramin fragment-DOCA conjugate by mimicking the action of low molecular weight heparins. Biomolecules 2020, 11, 46. [CrossRef] [PubMed]

79. Park, J.; Kim, J.Y.; Hwang, S.R.; Mahmud, F.; Byun, Y. Chemical conjugate of low molecular weight heparin and suramin fragment inhibits tumor growth possibly by blocking VEGF165. Mol. Pharm. 2015, 12, 3935-3942. [CrossRef]

80. Wen, J.; Chen, Q.; Ye, L.; Zhang, H.; Zhang, A.; Feng, Z. The preparation of pH and GSH dual responsive thiolated heparin/DOX complex and its application as drug carrier. Carbohydr. Polym. 2020, 230, 115592. [CrossRef]

81. Wu, Y.; Li, F.; Zhang, X.; Li, Z.; Zhang, Q.; Wang, W.; Pan, D.; Zheng, X.; Gu, Z.; Zhang, H.; et al. Tumor microenvironmentresponsive PEGylated heparin-pyropheophorbide-a nanoconjugates for photodynamic therapy. Carbohydr. Polym. 2021, 255, 117490. [CrossRef]

82. Xu, C.; Yang, S.; Jiang, Z.J.; Zhou, J.P.; Yao, J. Self-propelled gemini-like LMWH-scaffold nanodrugs for overall tumor microenvironment manipulation via macrophage reprogramming and vessel normalization. Nano Lett. 2020, 20, 372-383. [CrossRef] [PubMed]

83. Skidmore, M.A.; Kajaste-Rudnitski, A.; Wells, N.M.; Guimond, S.E.; Rudd, T.R.; Yates, E.A.; Vicenzi, E. Inhibition of influenza H5N1 invasion by modified heparin derivatives. Medchemcomm 2015, 6, 640-646. [CrossRef]

84. Helfer, H.; Siguret, V.; Mahe, I. Tinzaparin sodium pharmacokinetics in patients with chronic kidney disease: Practical implications. Am. J. Cardiovasc. Drugs 2020, 20, 223-228. [CrossRef] [PubMed] 
85. Tandon, R.; Sharp, J.S.; Zhang, F.M.; Pomin, V.H.; Ashpole, N.M.; Mitra, D.; Jin, W.H.; Liu, H.; Sharma, P.; Linhardt, R.J.; et al. Effective inhibition of SARS-CoV-2 entry by heparin and enoxaparin derivatives. J. Virol. 2021, 95, e01987-20. [CrossRef] [PubMed]

86. Thachil, J. The versatile heparin in COVID-19. J. Thromb. Haemost. 2020, 18, 1020-1022. [CrossRef] [PubMed]

87. Ayerbe, L.; Risco, C.; Ayis, S. The association between treatment with heparin and survival in patients with Covid-19. J. Thromb. Thrombolys. 2020, 50, 298-301. [CrossRef]

88. Jin, H.Z.; Chen, Q.; Zhang, Y.Y.; Hao, K.F.; Zhang, G.Q.; Zhao, W. Preactivation-based, iterative one-pot synthesis of anticoagulant pentasaccharide fondaparinux sodium. Org. Chem. Front. 2019, 6, 3116-3120. [CrossRef]

89. Galli, M.; Chatterjee, M.; Grasso, M.; Specchia, G.; Magen, H.; Einsele, H.; Celeghini, I.; Barbieri, P.; Paoletti, D.; Pace, S.; et al. Phase I study of the heparanase inhibitor roneparstat: An innovative approach for multiple myeloma therapy. Haematologica 2018, 103, E469-E472. [CrossRef]

90. Thomas, A.K.; Wieduwild, R.; Zimmermann, R.; Lin, W.; Friedrichs, J.; Bickle, M.; Fahmy, K.; Werner, C.; Zhang, Y. Layer-by-layer assembly of heparin and peptide-polyethylene glycol conjugates to form hybrid nanothin films of biomatrices. ACS Appl. Mater. Interfaces 2018, 10, 14264-14270. [CrossRef] [PubMed]

91. Hao, Y.; Gao, Y.S.; Wu, Y.D.; An, C.S. The AIB1siRNA-loaded hyaluronic acid-assembled PEI/heparin/Ca2+ nanocomplex as a novel therapeutic strategy in lung cancer treatment. Int. J. Mol. Med. 2019, 43, 861-867. [CrossRef]

92. Xiang, Z.; Wang, Y.; Ma, Z.; Xin, Z.; Chen, R.; Shi, Q.; Wong, S.C.; Yin, J. Inhibition of inflammation-associated thrombosis with ROS-Responsive Heparin-DOCA/PVAX Nanoparticles. Macromol. Biosci. 2019, 19, e1900112. [CrossRef]

93. Ismail, M.; Du, Y.; Ling, L.; Li, X. Artesunate-heparin conjugate based nanocapsules with improved pharmacokinetics to combat malaria. Int. J. Pharm. 2019, 562, 162-171. [CrossRef]

94. Maretti, E.; Pavan, B.; Rustichelli, C.; Montanari, M.; Dalpiaz, A.; Iannuccelli, V.; Leo, E. Chitosan/heparin polyelectrolyte complexes as ion-paring approach to encapsulate heparin in orally administrable SLN: In vitro evaluation. Coll. Surface A 2021, 608, 125606. [CrossRef]

95. Li, J.; Pan, H.; Qiao, S.; Li, Y.; Wang, J.; Liu, W.; Pan, W. The utilization of low molecular weight heparin-poloxamer associated Laponite nanoplatform for safe and efficient tumor therapy. Int. J. Biol. Macromol. 2019, 134, 63-72. [CrossRef]

96. Bi, Y.; Le, K.D.; Ramamoorthy, G.; Kuberan, B. Preparation and Application of Nanosensor in Safeguarding Heparin Supply Chain. SLAS Technol. 2020, 25, 397-403. [CrossRef] [PubMed]

97. Choi, J.U.; Kim, J.Y.; Chung, S.W.; Lee, N.K.; Park, J.; Kweon, S.; Cho, Y.S.; Kim, H.R.; Lim, S.M.; Park, J.W.; et al. Dual mechanistic TRAIL nanocarrier based on PEGylated heparin taurocholate and protamine which exerts both pro-apoptotic and anti-angiogenic effects. J. Control. Release 2021, 336, 181-191. [CrossRef] [PubMed]

98. Kim, S.Y.; Jin, W.; Sood, A.; Montgomery, D.W.; Grant, O.C.; Fuster, M.M.; Fu, L.; Dordick, J.S.; Woods, R.J.; Zhang, F.; et al. Characterization of heparin and severe acute respiratory syndrome-related coronavirus 2 (SARS-CoV-2) spike glycoprotein binding interactions. Antiviral. Res. 2020, 181, 104873. [CrossRef] [PubMed]

99. Zhao, J.; Kong, Y.; Zhang, F.; Linhardt, R.J. Impact of temperature on heparin and protein interactions. Biochem. Physiol. 2018, 7, 241. [CrossRef] [PubMed]

100. Sun, F.; Wang, Z.; Yang, Z.; Li, Y.; Cui, H.; Liu, C.; Gao, D.; Wang, F.; Tan, H. Characterization, bioactivity and pharmacokinetic study of a novel carbohydrate-peptide polymer: Glycol-split heparin-endostatin2 (GSHP-ES2). Carbohydr. Polym. 2019, 207, 79-90. [CrossRef] [PubMed]

101. Andrgie, A.T.; Mekuria, S.L.; Addisu, K.D.; Hailemeskel, B.Z.; Hsu, W.H.; Tsai, H.C.; Lai, J.Y. Non-anticoagulant heparin prodrug loaded biodegradable and injectable thermoresponsive hydrogels for enhanced anti-metastasis therapy. Macromol. Biosci. 2019, 19, e1800409. [CrossRef]

102. Moon, C.H.; Lee, J.Y.; Kim, E.S.; Park, J.H.; Kim, S.Y.; Kim, J.Y.; Tchah, H. In vivo biodistribution of topical low molecular weight heparin-taurocholate in a neovascularized mouse cornea. Int. J. Ophthalmol. Chi. 2018, 11, 1435-1439.

103. Kim, S.Y.; Zhang, F.M.; Gong, W.H.; Chen, K.Q.; Xia, K.; Liu, F.; Gross, R.; Wang, J.M.; Linhardt, R.J.; Cotten, M.L. Copper regulates the interactions of antimicrobial piscidin peptides from fish mast cells with formyl peptide receptors and heparin. $J$. Biol. Chem. 2018, 293, 15381-15396. [CrossRef] [PubMed]

104. Costanzo, L.; Palumbo, F.P.; Ardita, G.; Antignani, P.L.; Arosio, E.; Failla, G.; Invest, I.S.V.; Med, I.S.V. Coagulopathy, thromboembolic complications, and the use of heparin in COVID-19 pneumonia. J. Vasc. Surg. Venous Lymphat. Disord. 2020, 8, 711-716. [CrossRef]

105. Kwon, P.S.; Oh, H.; Kwon, S.J.; Jin, W.; Zhang, F.; Fraser, K.; Hong, J.J.; Linhardt, R.J.; Dordick, J.S. Sulfated polysaccharides effectively inhibit SARS-CoV-2 in vitro. Cell Discov. 2020, 6, 50. [CrossRef] [PubMed]

106. Mattioli, M.; Benfaremo, D.; Mancini, M.; Mucci, L.; Mainqua, P.; Polenta, A.; Baldini, P.M.; Fulgenzi, F.; Dennetta, D.; Bedetta, S.; et al. Safety of intermediate dose of low molecular weight heparin in COVID-19 patients. J. Thromb. Thrombolysis 2021, 51, 286-292. [CrossRef] [PubMed]

107. Tree, J.A.; Turnbull, J.E.; Buttigieg, K.R.; Elmore, M.J.; Coombes, N.; Hogwood, J.; Mycroft-West, C.J.; Lima, M.A.; Skidmore, M.A.; Karlsson, R.; et al. Unfractionated heparin inhibits live wild type SARS-CoV-2 cell infectivity at therapeutically relevant concentrations. Brit. J. Pharmacol. 2021, 178, 626-635. [CrossRef] [PubMed]

108. Seffer, M.T.; Cottam, D.; Forni, L.G.; Kielstein, J.T. Heparin 2.0: A new approach to the infection crisis. Blood Purificat. 2021, 50, 28-34. [CrossRef] [PubMed] 
109. Torres, F.G.; Troncoso, O.P.; Pisani, A.; Gatto, F.; Bardi, G. Natural polysaccharide nanomaterials: An overview of their immunological properties. Int. J. Mol. Sci. 2019, 20, 5092. [CrossRef]

110. Rajora, A.K.; Ravishankar, D.; Zhang, H.; Rosenholm, J.M. Recent advances and impact of chemotherapeutic and antiangiogenic nanoformulations for combination cancer therapy. Pharmaceutics 2020, 12, 592. [CrossRef]

111. Lim, S.; Park, J.; Shim, M.K.; Um, W.; Yoon, H.Y.; Ryu, J.H.; Lim, D.K.; Kim, K. Recent advances and challenges of repurposing nanoparticle-based drug delivery systems to enhance cancer immunotherapy. Theranostics 2019, 9, 7906-7923. [CrossRef]

112. Park, J.; Choi, Y.; Chang, H.; Um, W.; Ryu, J.H.; Kwon, I.C. Alliance with EPR Effect: Combined Strategies to Improve the EPR Effect in the Tumor Microenvironment. Theranostics 2019, 9, 8073-8090. [CrossRef]

113. Qiu, X.L.; Fan, Z.R.; Liu, Y.Y.; Wang, D.F.; Wang, S.X.; Li, C.X. Preparation and evaluation of a self-nanoemulsifying drug delivery system loaded with heparin phospholipid complex. Int. J. Mol. Sci. 2021, 22, 4077. [CrossRef]

114. Nurunnabi, M.; Khatun, Z.; Moon, W.C.; Lee, G.; Lee, Y.K. Heparin based nanoparticles for cancer targeting and noninvasive imaging. Quant. Imag. Med. Surg. 2012, 2, 219-226.

115. Kim, S.K.; Kim, K.; Lee, S.; Park, K.; Park, J.H.; Kwon, I.C.; Choi, K.; Kim, C.Y.; Byun, Y. Evaluation of absorption of heparin-DOCA conjugates on the intestinal wall using a surface plasmon resonance. J. Pharm. Biomed. Anal. 2005, 39, 861-870. [CrossRef] [PubMed]

116. Park, J.; Hwang, S.R.; Choi, J.U.; Alam, F.; Byun, Y. Self-assembled nanocomplex of PEGylated protamine and heparin-suramin conjugate for accumulation at the tumor site. Int. J. Pharm. 2018, 535, 38-46. [CrossRef] [PubMed]

117. Alam, F.; Al-Hilal, T.A.; Chung, S.W.; Park, J.; Mahmud, F.; Seo, D.; Kim, H.S.; Lee, D.S.; Byun, Y. Functionalized heparinprotamine based self-assembled nanocomplex for efficient anti-angiogenic therapy. J. Control. Release 2015, 197, 180-189. [CrossRef] [PubMed]

118. Wan, X.; Li, P.; Jin, X.; Su, F.; Shen, J.; Yuan, J. Poly(epsilon-caprolactone)/keratin/heparin/VEGF biocomposite mats for vascular tissue engineering. J. Biomed. Mater. Res. A 2020, 108, 292-300. [CrossRef] [PubMed]

119. Sarich, T.C.; Seltzer, J.H.; Berkowitz, S.D.; Costin, J.; Curnutte, J.T.; Gibson, C.M.; Hoffman, M.; Kaminskas, E.; Krucoff, M.W.; Levy, J.H.; et al. Novel oral anticoagulants and reversal agents: Considerations for clinical development. Am. Heart J. 2015, 169, 751-757. [CrossRef]

120. Testa, S.; Paoletti, O.; Giorgi-Pierfranceschi, M.; Pan, A. Switch from oral anticoagulants to parenteral heparin in SARS-CoV-2 hospitalized patients. Intern. Emerg. Med. 2020, 15, 751-753. [CrossRef]

121. Wysokinski, W.E.; Houghton, D.E.; Casanegra, A.I.; Vlazny, D.T.; Bott-Kitslaar, D.M.; Froehling, D.A.; Hodge, D.O.; Peterson, L.G.; McBane, R.D. Comparison of apixaban to rivaroxaban and enoxaparin in acute cancer-associated venous thromboembolism. Am. J. Hematol. 2019, 94, 1185-1192. [CrossRef] [PubMed]

122. Kumano, O.; Akatsuchi, K.; Amiral, J. Updates on anticoagulation and laboratory tools for therapy monitoring of heparin, vitamin K antagonists and direct oral anticoagulants. Biomedicines 2021, 9, 264. [CrossRef]

123. Eriksson, B.I.; Borris, L.C.; Friedman, R.J.; Haas, S.; Huisman, M.V.; Kakkar, A.K.; Bandel, T.J.; Beckmann, H.; Muehlhofer, E.; Misselwitz, F.; et al. Rivaroxaban versus enoxaparin for thromboprophylaxis after hip arthroplasty. N. Engl. J. Med. 2008, 358, 2765-2775. [CrossRef] [PubMed]

124. Xing, J.L.; Yin, X.B.; Chen, D.S. Rivaroxaban versus enoxaparin for the prevention of recurrent venous thromboembolism in patients with cancer A meta-analysis. Medicine 2018, 97, 132-139. [CrossRef]

125. Beurskens, D.M.H.; Huckriede, J.P.; Schrijver, R.; Hemker, H.C.; Reutelingsperger, C.P.; Nicolaes, G.A.F. The Anticoagulant and Nonanticoagulant Properties of Heparin. Thromb. Haemost. 2020, 120, 1371-1383. [CrossRef] [PubMed]

126. Lipowsky, H.H.; Lescanic, A. Inhibition of inflammation induced shedding of the endothelial glycocalyx with low molecular weight heparin. Microvasc. Res. 2017, 112, 72-78. [CrossRef]

127. Peysselon, F.; Ricard-Blum, S. Heparin-protein interactions: From affinity and kinetics to biological roles. Application to an interaction network regulating angiogenesis. Matrix Biol. 2014, 35, 73-81. [CrossRef] [PubMed]

128. Lima, M.; Rudd, T.; Yates, E. New applications of heparin and other glycosaminoglycans. Molecules 2017, 22, 749. [CrossRef] 